\title{
4. Drug Controls in Iceland: Any Retreat in Sight?
}

Helgi Gunnlaugsson

\section{Introduction}

The majority of nations, including the Nordic countries, still penalize the production, distribution, and personal possession of certain types of drugs. In this chapter, the Icelandic drug situation and drug legislation will be examined (pop. 370,000). Iceland has, over time, adopted a restrictive response to the production, possession, and sale of drugs modeled after international legal policy measures. The study draws on official documents, such as police and local public health statistics, survey data, records of parliamentary debate, media accounts, and previous research. The legal situation regarding drugs is described, depicting both historical and current legal changes that have, and are, taking place in Iceland. Noteworthy events in the local debate on drugs during two different time periods are presented and discussed. First, the period of I980-2000, followed by later developments in the new millennium. The number and nature of drug cases known to the police is examined during the period of 20IO-20I9, in addition to what substances have been seized by police during the same period. Prevalence of cannabis use among adults over time, the most frequently used drug in Iceland, is presented and analyzed, with a focus on what local research indicates as characterizing drug use in general. The opioid crisis recently hit Iceland, dominating the public debate on drugs. Figures presented involving drug-related deaths show how much opioids are implicated in these deaths.

How to cite this book chapter:

Gunnlaugsson, Helgi. Drug Controls in Iceland: Any Retreat in Sight? In: Retreat or Entrenchment? Drug Policies in the Nordic Countries at a Crossroads, edited by Henrik Tham, 67-Ior. Stockholm: Stockholm University Press, 202I. DOI: https://doi.org/IO.I6993/bbo.d. License: CC BY 4.0 . 
In the wake of a public debate about drug abuse in society, signs of a retreat in the control of drugs can be detected in the most recent years in Iceland. Instead of a predominantly criminal justice response toward possession of drugs, abuse of drugs is increasingly being viewed as a public health problem. A case in point demonstrating this shift is a recent legal change allowing safe havens for drug addicts, in addition to a $202 \mathrm{I}$ proposal, yet not passed, from the Minister of Health decriminalizing the possession of drugs for personal use. However, a major shift toward a radically different drug policy is contended to be unlikely in Iceland unless a broader legal change occurs internationally. Finally, an attempt is made to explain why concerns about drugs have become so profound in recent decades.

\section{Concern Over Substance Use in Iceland}

Iceland has a long history of national concern over substance use. Alcohol, for example, was prohibited from I9I 5-I922 and beer was illegal until I989 (Gunnlaugsson 20I7). However, the revoking of beer prohibition did not signal the end of the struggle against intoxicating substances in Iceland. A rejuvenated rigor took over Icelanders' battle against drugs, which has not yet faded. Interestingly, the arguments used to justify the ban on beer are not dissimilar to those we observe today to justify the prohibition of drugs (Gunnlaugsson 20I2). The advocates of beer prohibition repeatedly argued that beer posed a threat to the health and well-being of society, primarily to young people, just as is currently seen today with cannabis and other drugs.

Several different kinds of measures have been employed in the fight against drugs in Iceland over time. On one hand, we see various non-punitive measures being adopted - drug prevention drives, educational programs, peer group efforts in school, etc. - all with the objective of teaching young people to say No to Drugs, or political campaigns such as Drug Free Iceland by 2000 , to cite a few examples (Einarsson \& Björnsson 200I). Substance use treatment has also been readily available for decades in Iceland. Accessibility to treatment is believed to be high, resulting in a smaller treatment gap than in most other countries (Hansdóttir, Rúnarsdóttir, \& Tyrfingsson 2015). More than two 
thousand individuals are admitted to treatment clinics for alcohol and drug related problems in Iceland each year, including about six hundred new admissions.

In most recent years, Iceland has been internationally recognized for its success with the Youth in Iceland project (see, for example, Young 20I9). The project includes several components linking together research, policy, and practice. Local social scientists play a key role in mapping out the scope of the substance use problem and in identifying different risk factors. Moreover, state funding for organized leisure activities among youth was increased and children banned from being outside after specific hours at night, to name a few of the measures adopted in the program. Teenage consumption of alcohol, drugs, and tobacco was significantly cut in the new millennium. This positive development has predominantly been linked to the various prevention measures employed among youth in Iceland in cooperation with their parents and local community. Non-punitive policy measures against alcohol and drug use are presumably associated, with satisfying results.

Contrarily, various punitive policies are also being employed. This refers to criminal justice responses: drug possession for personal use being sanctioned by the special penal code; importation of drugs; and production and sale being heavily sanctioned by criminal law (Gunnlaugsson \& Galliher 2000; Gunnlaugsson 2OI 5). Many of the drug police enforcement practices have been shown to be influenced by US drug control policies, not only in Iceland but throughout the world (Gunnlaugsson \& Galliher I995; Nadelmann I993). Undercover practices were encouraged by US agents to be integrated into drug police investigations, and Icelandic drug police officers were sent to the US for training in American methods of narcotics control (Mannlif I992).

\section{Legal Status of Drugs in Iceland}

Icelandic legislation on controlled substances dates back to I923, when an international drug convention, of which Iceland was a member, passed what has been referred to as the opium laws. These laws, in charge of the Ministry of Justice, were largely unenforced, but in the late I960s, with international concern about 
drug use among the young heating up, Iceland's narcotics laws were revised and extended to make cannabis and LSD illegal also (Gunnlaugsson \& Galliher 2000). In I974, new drug laws were passed by Alpingi (the Icelandic parliament), which were intended to replace the old opium laws by imposing more severe penalties for major drug violations. These laws were officially intended to unify and coordinate laws against the alleged 'use of drugs which is becoming a serious social problem manifested in scientific revelations of the harmfulness of these substances' (preamble to law no. 65/1974). For major violations, a person could be sentenced to a maximum of $\mathrm{o}$ years in prison, instead of six years, as provided for in the opium laws.

In contradiction to a I95 I legislation separating the police and the courts, in I973 Alpingi established law no. 52, a specialized drug police unit to be supervised by a separate drug court. The creation of this joint police-court apparatus in Reykjavík demonstrates the degree of concern associated with this new and frightening problem in Iceland. The total number of drug police officers was seven in 1984 and had increased to approximately 20 by the new millennium, making it the largest specialized police force in the nation (Gunnlaugsson \& Galliher 2000). Complete separation of the executive and judicial powers was not achieved until I 992. Consequently, the independent drug court in Reykjavík was disbanded in the same year. Still, the separate drug police force was operational until 2016, when a centralized police investigation unit was established to deal with different types of crime. One of the primary tasks of this new unit was to investigate the importation and distribution of drugs.

The maximum penalty for drug offenses as of $202 \mathrm{I}$ is I 2 years in prison, with the upper limit being increased from ro years in $200 \mathrm{I}$ in the wake of the entrance of ecstasy in the country. The possession of drugs for personal use is prohibited in Iceland by the local special penal code (law no. 65/I974). Blood or urine samples are not used by police to establish pure use of drugs, apart from in instances involving the driving of a vehicle - only possession of drugs is punishable. The violation of this article, until 2018, was followed by a note in the criminal record of the offender and maintained for a period of three years. Despite this 
three-year period, a violation of this code was accessible to local authorities for longer than three years - up to ro years ( $\mathrm{Mbl}$.is 20I4). Local employers are increasingly asking for the criminal records of job applicants; thus, being on record for a drug violation can easily jeopardize future job prospects of those caught for the personal possession of drugs.

\section{Drugs in Iceland during 1980-2000}

The criminal justice approach to drugs has been supported by politicians and members of Alpingi from the beginning. Criticism of the punitive approach was hardly ever voiced in the 20 th century in Alpingi and alternative policies have only been introduced in the last few years. A case in point from the I980's is an Alpingi resolution following two relatively large cases of importation of cannabis to Iceland, which was passed unanimously. The proposal called for increased cooperation and coordination between customs and other control agencies, and an improvement in all investigative police methods. As stated by the sponsor of this bill, '... we have seen terrifying figures which strongly suggest that there is enormous consumption of drugs in society and that only a tiny portion [is] being seized by control people ... drug use ruins the lives of a number of young people' (Alpingi Debates I983I984a:2). Another MP noted during the debates that 'Powerful crime cartels have reached Iceland, and ruthlessly their drug dealers bring their nets to grab young people who, suspecting no evil, subsequently become addicted' (Alpingi Debates I983-I984b: I).

An example of a punitive practice is police searches of private homes, which have occurred frequently over the years (Gunnlaugsson \& Galliher 2000). In the I980's and I990's, up to 200 such searches were conducted annually by the police, either with a warrant or without. On average, approximately 500 persons were arrested each year from I 987 to I994 on suspicions of drug violations, when the total population of Iceland was approximately 250,000 (Gunnlaugsson \& Galliher 2010). Most involved private possession $(75 \%)$, and the remainder involved sales and importation. Wiretapping has also routinely been employed. During a three-year period in the early I990's, the courts 
issued a total of 29 warrants permitting the police to tap a total of 42 telephone numbers for up to 2 months, all cases involving drug violations.

A deputy director of the local drug police had previously stated in a local media interview that the drug problem had intensified in recent years in Iceland, or since drugs first appeared in Iceland around I970 (Morgunblaðið I979). He stated that since the creation of the drug police, a total of 4000 young people had been implicated in drug investigations, that young people had died because of drug use, and that heroin had made its entry into Iceland. News reports, such as this one, have been frequent over the years in Iceland. Escalating drug use among youth, largescale drug seizures, mass arrests for drug smuggling and sales, and long-term prison sentences typically make the headlines (see, for example, Gunnlaugsson \& Galliher 2010). Nevertheless, in I979, when the news report was published, no official evidence suggested the deaths of young people were due to drug overdoses (Kristmundsson I985) and very few signs indicated the existence of heroin in Iceland, which is still the case today (see Table I I). Even though this news reporting appears exaggerated today, suggesting a moral panic, as often seems to be the case with drug media reporting (Goode \& Yehuda 2009), this news report can also be viewed as a public warning and a call for serious steps to be adopted by local authorities toward this new social challenge facing the nation.

The most notorious drug police case resolved during this era, which was inspired by US undercover techniques, was an agreement made in 1992 with an ex-convict who was asked to operate as an agent provocateur (Gunnlaugsson \& Galliher 1995). The agent was asked to purchase $1.2 \mathrm{~kg}$ of cocaine from an acquaintance whom he had met in prison the preceding year. The acquaintance was reportedly not interested in selling the drugs in Iceland. However, the informant was persistent and the acquaintance grudgingly agreed to sell most of the drugs he had in his possession, even though it was originally planned for sale in Denmark. The director of the drug police and several of his officers, with none of the latter being informed of the complete story, subsequently initiated a major drug bust. This involved a car chase in which an officer was seriously injured. An Icelandic 
law school textbook argues that such law enforcement practices are hardly within legal limits and, by all means, it is better that a police officer be an agent rather than an ordinary citizen, with it not being feasible to use convicts to meet the demands of an investigation (Pórmundsson I980). However, the Supreme Court confirmed the seven-year sentence against the suspect, even though the court recognized that the director had not consulted sufficiently with the Reykjavík police. Despite this lack of consultation, it was not believed to be enough to grant acquittal or reduction of the penalty (Morgunblaðið I993).

According to police records, cannabis was the most common of the illegal substances seized in Iceland in the I980's and I990's. LSD occasionally popped up, with amphetamines in powder form being stable on the market and cocaine entering the market in the I990s (Gunnlaugsson \& Galliher 2000). Close to I $50 \mathrm{~kg}$ of cannabis, or more than $80 \%$ of the drugs seized by the drug police during the I985-I995 period, involved cannabis, approximately I $5 \mathrm{~kg}$ of amphetamines, less than $4 \mathrm{~kg}$ of cocaine, and a few thousand doses of LSD.

In the mid I990s, with the entry of ecstasy in Iceland, the drug problem escalated to new dimensions. Soon after the substance appeared, its use created a major public uproar and insecurity in Iceland. Jónasson and Gunnlaugsson (2015) have identified all the elements of a moral panic in Icelandic society with the appearance of the ecstasy tablet. Initially, it was the police, media, and other interest groups that predominantly focused on ecstasy use and the threat it posed to the Icelandic society. The public, subsequently, demanded through various grassroots efforts that the government act promptly, painting drug dealers as folk devils who should receive much harsher punishment. The state, consequently, responded to this public outcry by making punishment heavier, promising more funds to the drug police, and agreeing on new police laws.

\section{Drugs in Iceland in the 2000's}

In the new millennium, drug cases increased in Iceland, with a variety of different drugs being seized by the police. During 20022007 , the police seized more than $200 \mathrm{~kg}$ of cannabis, more than 
Iookg of amphetamines, and approximately 3 okg of cocaine. The number of doses of ecstasy and LSD seized were also in the tens of thousands during the same period (National Commissioner of the Icelandic Police 2008).

In 2007 and 2009, the total amount of drugs seized from two boats on the east coast of Iceland exceeded all the drugs seized by police during the entire 2002-2007 period. In the 2009 boat case, labeled as 'skútumálið' (the yacht case), the police seized a total of $55 \mathrm{~kg}$ of amphetamines, $54 \mathrm{~kg}$ of cannabis, and about 9000 ecstasy tablets. The six people implicated in the case received a total of 40 years in prison for this attempt to smuggle drugs into Iceland (Supreme Court 2009). Moreover, reportedly home-grown marijuana was increasingly replacing importation of cannabis, with hundreds of plants seized by local police and numerous individuals arrested (Visir.is 2007).

During 20I4 to 20I8, wiretapping was used even more frequently than before by the police, and requests for the same were very seldom rejected by the courts. A total of $25 \mathrm{I}$ permits were issued to the police to tap phones, with about one quarter involving drugs (Böðvarsdóttir 2020). Police searches of suspicious persons for drugs and at random have routinely been resorted to by the local police, in addition to the use of sniffer dogs for looking for drugs, especially where young people hang out, at local music festivals, etc. (Mbl.is 20I8). Dog sniffing of passenger baggage at airports and docks is also customary, with international mail and parcels from abroad being scrutinized by customs in local post offices.

In 20I6, two persons were sentenced to eight and four years in prison for the importation of I93g of cocaine, Io,000 MDMA doses, and $9 \mathrm{~kg}$ of amphetamines through the international airport in Keflavík. This case was labeled as 'burðardýrsmálið' (drug mule case) and included smuggling from Holland (Supreme Court 2016). The person who received eight years in prison, a Dutch woman, attempted to help the police in catching the principal offender but to no avail. The stiff sentence she was awarded for simply being a drug courier was reportedly due to the amount of hard drugs being smuggled. How many of the inmate population in Iceland have served time in prison for drug-related offenses? 
In the 2 Ist century, about one third of the entire inmate population has routinely been serving time in prison for drug-related offenses. In 20I 8 and 20I9, the ratio of drug offenders reached a historic high of $40 \%$ of the total inmate population (Prison and Probation Administration 2020). In 2016, a total of Ioo inmates served time in prison for drug importation, production, or sale. In the I980s, and well into the I990s, the rate of drug offenders in prison was considerably lower, less than I०\% of the prison population (Gunnlaugsson \& Galliher 2000).

\section{Drug Crimes Known to the Police}

Figure 9 indicates the number of drug violations recorded by the Icelandic police each year since $20 \mathrm{I} 0$, followed by Table I I, which shows the type and amounts of drugs being seized by the police. Both show an increase in the new millennium.

As can be seen in Figure 9, the total number of drug offenses increased markedly during 20IO-20I4, from about I 500 offenses in 2010 to about 2400 offenses in 2014 , a peak year. Since 2015 ,

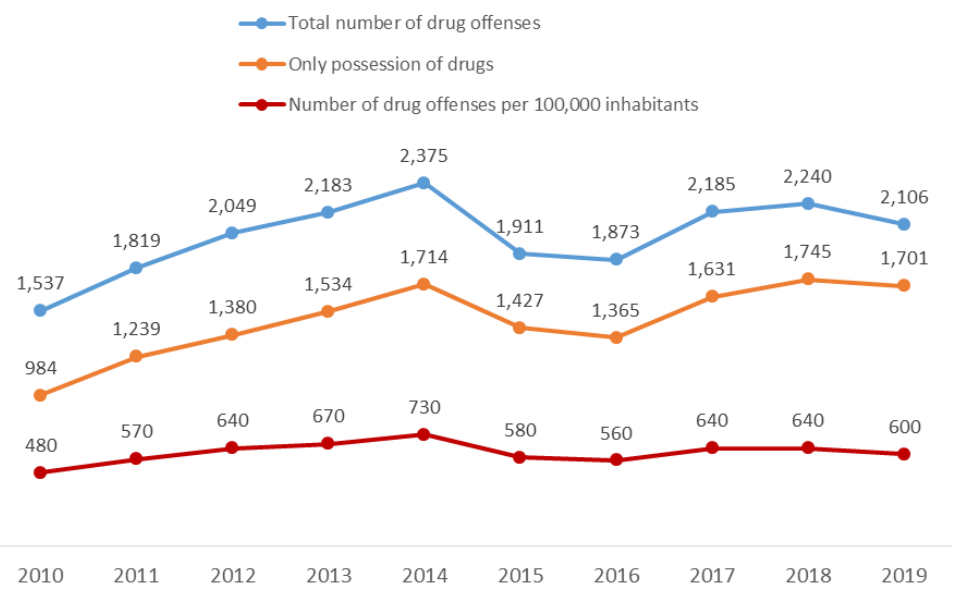

Figure 9. Total number of drug offenses in Iceland, 2010-2019, including only possession of drugs, and the number of offenses per I00,000 inhabitants.

Source: National Commissioner of the Icelandic Police, annual reports, 2020. 


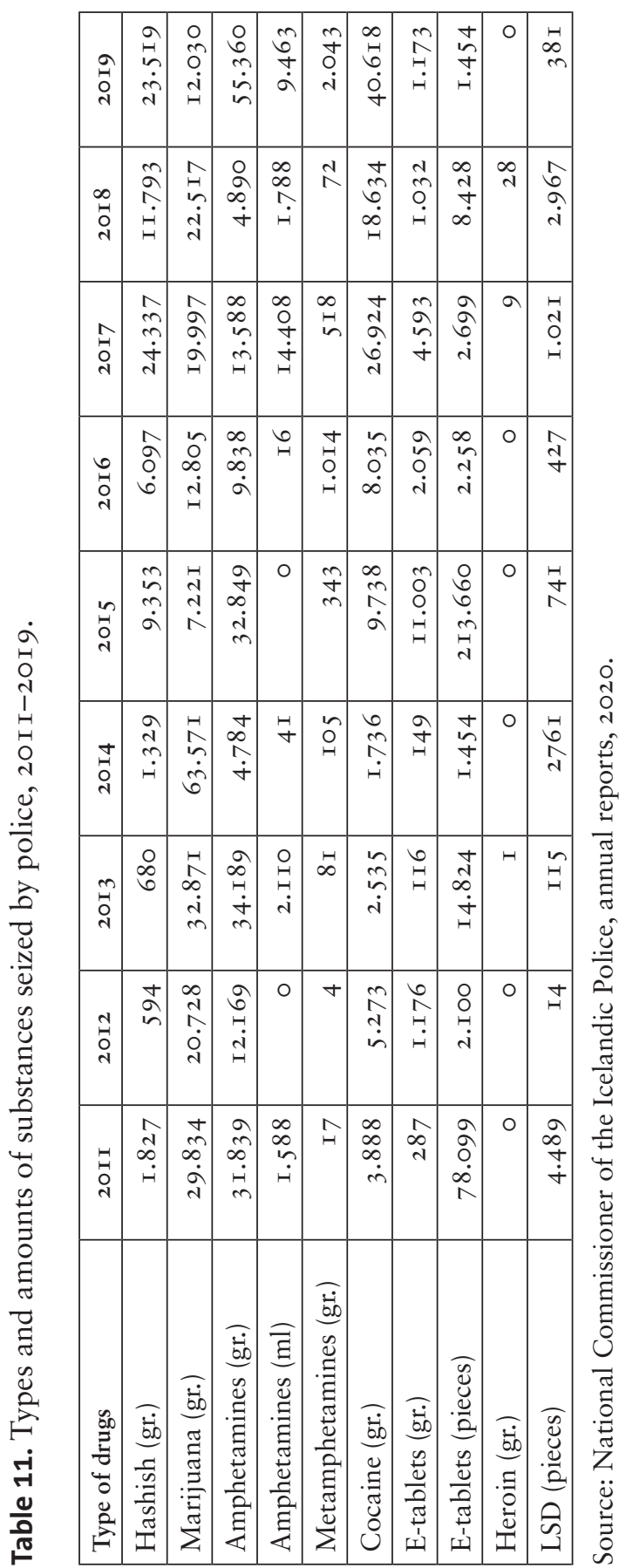


the total number each year has become more stable, with about 2000 offenses registered annually in Icelandic police records, including cases under police investigation for suspicion of drug violations (National Commissioner of the Icelandic Police 2020).

These offenses, as before, consist predominantly of possession of drugs and, in smaller portions, of importation, production, and distribution of drugs. About $70 \%$ of these offenses involved the possession of drugs for personal use. As can also be seen in Figure 9, the number of drug offenses known to the police has been hovering around 600 offenses per 100,000 inhabitants during most recent years.

As can be seen in Table I I, a variety of drugs have been seized by police in the past few years. The total amount of drugs apparently increased during the time period 20II-20I9. The most notable increases included cannabis, cocaine, and amphetamines, with a peak year in 2019. Most of the drugs seized by the police in 2019 comprised of amphetamines $(55 \mathrm{~kg})$, cocaine $(40 \mathrm{~kg})$, cannabis (hashish/marijuana) $(35 \mathrm{~kg})$, and about 2500 ecstasy doses. Heroin was hardly ever seized by police during this time period.

The minimum fine stipulated for possession of drugs is approximately $€_{35}$ o for cannabis and more for ecstasy and cocaine. If the amount of cannabis seized is Iog, the fine is approximately $€ 650$ (Ministry of Justice 20I 8). Many of the drug offenses for possession of drugs occur during routine police checks on the road or while investigating criminal cases where drugs are found on crime suspects etc. With the legal change in 201 8 , drug fines of less than I००,००० Icelandic kronas (approximately $€_{700)}$ ) are no longer registered on the criminal record. The Justice Minister reported in Alpingi to a query by a Pirate Party member of parliament, that if the legal change had been made 6 months earlier, more than Io० persons only registered on criminal record for a minimum drug fine would have escaped this notification (Ministry of Justice 20I 8).

The ratio of those driving while on drugs has increased significantly in recent years (National Commissioner of the Icelandic Police 2020). In 2014, the total number of cases of driving while intoxicated (and not inebriated) was slightly short of I 500 . In 2018 , the number had reached almost 2500 . In 2018 , the number 
of cases of driving while intoxicated on alcohol was about 1700 - or a significantly lower number than the cases involving drugs. The overall rate of driving while intoxicated from alcohol or other drugs had previously been found to be comparatively high in Iceland (Gunnlaugsson \& Galliher 2000).

\section{Nature and Extent of Drug Use in Iceland}

International surveys indicate that drug use among Ioth graders is generally lower in Iceland than in most other European countries (ESPAD 2020). The average in Iceland for lifetime prevalent use of cannabis, by far the most frequently used illegal drug, was, for example, $6 \%$ in 2019 , while the European average (16\%) was significantly higher. Iceland had the lowest levels of cannabis use among Nordic nations, with Sweden (8\%), Faroe Islands (9\%), and Norway $(9 \%)$ coming close to Iceland. Finland (I \% $\%$ ) and Denmark ( $\mathrm{I} 7 \%)$, however, reported higher levels. As mentioned above, the Youth in Iceland project has been cited as being decisive in the positive development of drug use among youth in Iceland, with lower rates in 2019 than in previous ESPAD surveys.

Surveys of cannabis use among Icelandic adults (citizens over I 8 years old) have not been measured as regularly as among adolescents. Population surveys conducted by the Social Sciences Research Institute, affiliated with the University of Iceland, during I997-2019 suggest an increase in the lifetime prevalence of cannabis use (Figure Io) in this time period. Approximately $33 \%$ admitted to using cannabis at least once in 2019, with close to $5 \%$ admitting to its use in the last 6 months (Gunnlaugsson \& Jónasson 2019). As Figure Io shows, this suggests an increase from 2013 , when the lifetime figure was $23 \%$, and 2002, when the figure was $19 \%$.

Therefore, use of cannabis among youth appears to be going down over time but, at the same time, increasing in the adult population. According to the 2019 survey of cannabis use among adults in the last 6 months $(5 \%)$, as shown in Figure IO, it can be roughly estimated that up to I 5,000 might be active cannabis users in Iceland, out of a total population of around 370,000 citizens. In comparison, active users of alcohol have been estimated to be at least half of the adult population (Directorate of 


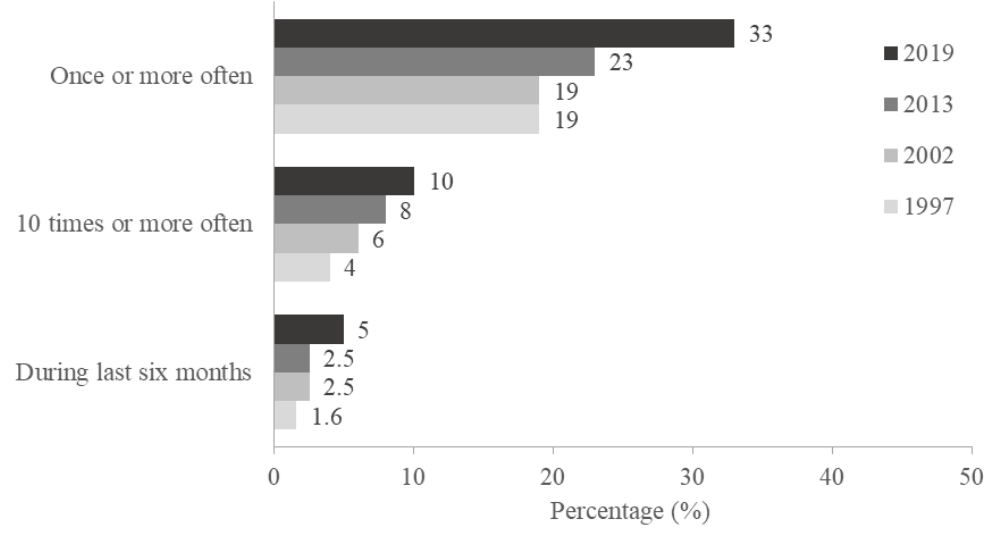

Figure 10. Percentage among adults ( 18 yrs and older) admitting cannabis use in their lifetime in 1997, 2002, 2013, and 2019. Source: Gunnlaugsson 20I8; Gunnlaugsson \& Jónasson 2019.

Health 20I7), or much higher than levels of cannabis use. The apparent pattern of cannabis use among adults is described in the section below.

As Figure II suggests, most lifetime use seems to take place among younger age groups. Use appears to be experimental, temporary, perhaps most out of curiosity, many discontinuing its use altogether when they grow older as work and family obligations gain precedence (Gunnlaugsson 20I8). Prevalence of this type of use over time probably linked to fashion waves, music taste, and other cultural fads - mostly international in nature - among younger age groups. Occasionally, experimental and social use appear to be trendy in popular culture and accompanied by increased access to drugs and more use, sometimes being less trendy with less use. The next sections further analyze drug abuse in this group.

Only a minority of these temporary users seem to require help from the social and health care services because of their use, i.e. the vast majority of this group are not drug abusers. These users are, for the most part, ordinary citizens who are not involved in any other forms of criminality, apart from using illicit drugs. However, all of them are at risk of being pursued by the police and criminal courts. Understandably, none of them want police involvement or criminal indictment for their use of drugs. 


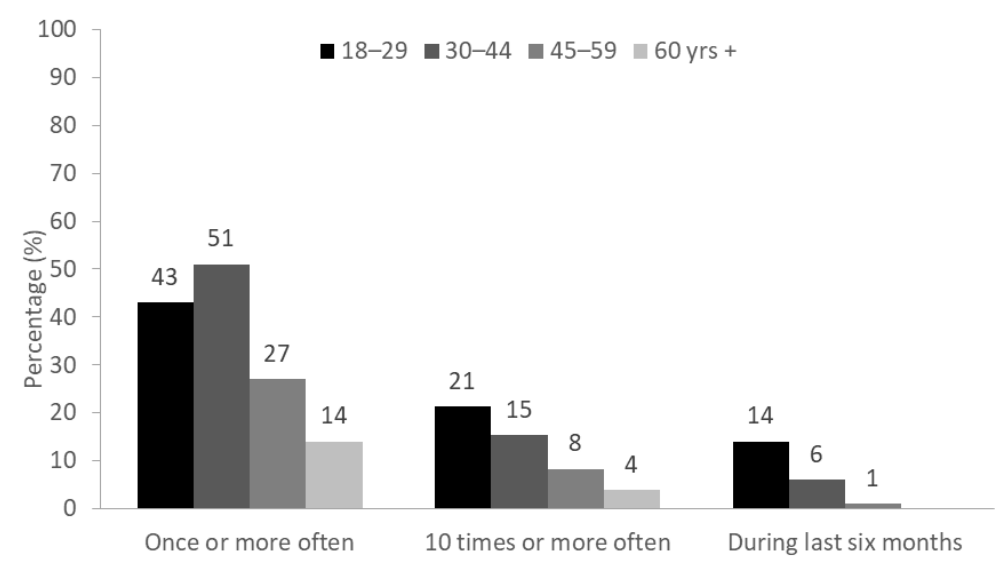

Figure 11. Percentage of adults older than I 8 yrs who, in 20I9, admitted cannabis use in their lifetime, by age.

Source: Gunnlaugsson \& Jónasson (2019).

Therefore, a pressing question emerges: Where is the drug abuse problem most pronounced? Interestingly, the most pressing and recent drug problem in Iceland has not only involved illegal drugs but also drugs originating mostly from the pharmaceutical industry and the medical profession.

\section{Icelandic Opioid Crisis}

With respect to legally prescribed drugs originating from the pharmaceutical industry, the picture for Iceland becomes more complicated than that suggested from the above picture of experimental and temporary drug use in Iceland (Gunnlaugsson 2019). The use of prescription drugs, or other synthetic drugs, seems to be widespread across different social groups, rather than being found only among socially distinct groups.

Apparently, a lot of prescription drugs are in circulation in Iceland. According to Nomesco (2017), more opioids are prescribed in Iceland than in any other Nordic country. Iceland also appears to be the leading Nordic country with respect to prescribing medical treatment for ADHD and in terms of antidepressant consumption. In the last decade, the use of antidepressants reportedly increased by about half in Iceland, and the use of 
ADHD prescription drugs exhibited a whopping I $65 \%$ increase (Arnórsson 2018). Even though prescriptions for insomnia and of sedatives have decreased somewhat in the country in the last decade, Iceland still leads Nordic nations for consumption of these drugs, also ranking among the highest in the world. Moreover, close to $20 \%$ of all women and about 10\% of all men in Iceland received a prescription for an antidepressant in 20I7. Most of the increase for these prescriptions in recent years has been among those who are 40 years old or younger (Jónsson $2018 \mathrm{a}$ ).

Some of the opioid prescriptions end up on the black market. In addition to other sources, the smuggling of medical drugs from other countries is also prevalent. According to the head physician at a local rehab center, access to different types of drugs - both legal and illegal - is easy in Iceland and their prices have remained stable or reduced (Ólafsdóttir 20I9). A new comparative Nordic study on drug dealing over social media platforms observed a high degree of drug dealing activity in Iceland. All kinds of drugs are available in closed groups, including prescription drugs in addition to illegal drugs (Demant et al. 2019). A total of 30 private Facebook groups with several thousand members were found online in Iceland. One seller in these groups stated in an interview, 'my customers are just ordinary citizens.' Recently, news reports have shown large seizures of cocaine by police (see Table I I), with cocaine reportedly flooding the market like never before (Brynjólfsson 20I9; Helgason 20I9).

\section{High Number of Drug-Related Deaths}

The medical drug situation in Iceland described above may come as a surprise since Iceland is a country of low drug use according to the ESPAD study of young students mentioned above. Furthermore, this claim might be unexpected since Icelanders consume less alcohol than most western nations, even though the gap between Iceland and other countries has been shrinking (OECD Health Statistics 2020). The opioid situation in Iceland has created significant national concern because opiates are highly addictive and can easily result in different types of health risks, in addition to other problems, such as accidents on the roads. 
Moreover, opiates are often used with other substances, such as alcohol and other drugs, thereby creating toxic cocktails.

Resultantly, numerous drug-related deaths have been reported in Iceland. From 2015 to 2017 , a total of 85 drug-related deaths from different drug-related intoxications were reported (see Figure I 2), including a total of 42 citizens dying due to opiate abuse. Opiate abuse was the most frequent cause of deaths due to intoxications for this time period, exceeding deaths due to illegal drugs by a large margin. The opiates mostly consisted of morphine, codeine, demerol, tramadol, and fentanyl (Jónsson 2018b). In 2018 , as can be seen in Figure I 2, a total of 39 related deaths in Iceland were reportedly related to drug overdoses, and more than half of them were opioid-related (Magnúsdóttir 20I9; Yaghi 2019). According to the New York Times, deaths due to opioid drug overdoses are comparatively high in Iceland, and about half of the rate in the US (Katz 20I7). This rate translated to 6.6 deaths per I00,000 Icelandic citizens in 2018 . The total rate of drug-related deaths during 2010-20I9 was however higher, as can be seen in Figure I2. The total rate of drug-related deaths during 2010-20I9 was from 7.I-II.I deaths per I00,000 inhabitants, as can be seen in Figure I2. Moreover, as shown in Figure I3, males had a higher drug-related death rate than females for most of this time period.

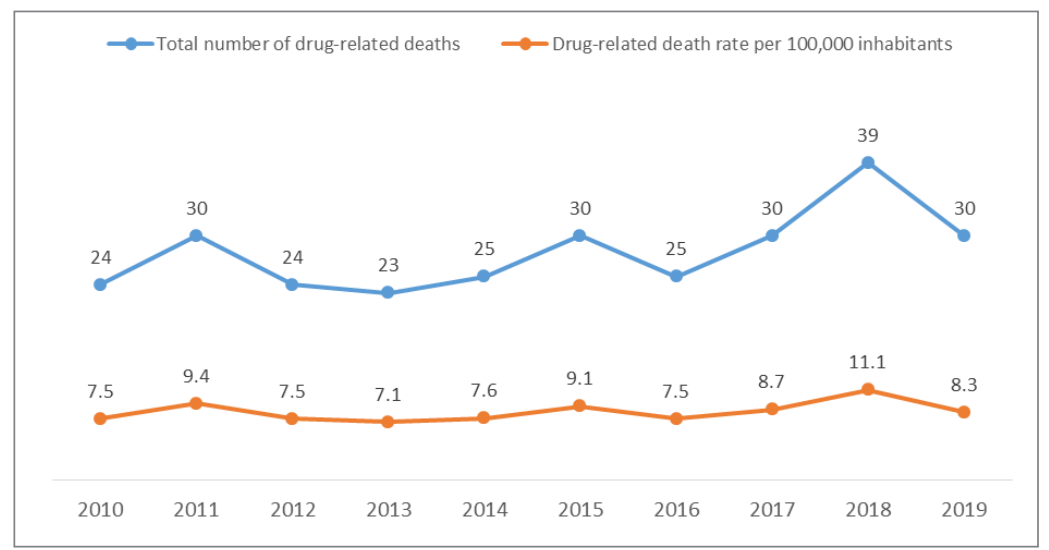

Figure 12. Total number of drug-related deaths and drug-related death rate, 20I0-20I9.

Source: Directorate of Health $202 \mathrm{I}$. 


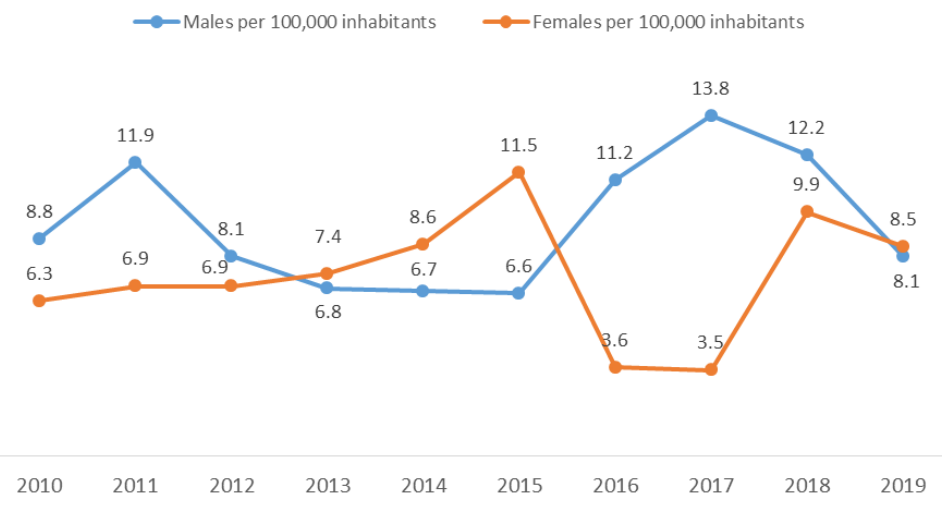

Figure 13. Drug-related death rate per I00,000 inhabitants in Iceland by gender, 2010-2019.

Source: Directorate of Health $202 \mathrm{I}$.

Why does the situation of prescription drugs and drug-related deaths appear so grim in Iceland? Perhaps prescription drugs are more accessible in Iceland than, for example, in the other Nordic nations. The Directorate of Health in Iceland, therefore, established an online prescription database for physicians in 2016 to prevent people from receiving multiple prescriptions for medications from different doctors. In July of 2018 , regulations concerning prescription drugs were tightened further, making it more challenging than before to legally obtain drugs of this type. The impact of tighter regulations has indeed resulted in fewer opiate prescriptions in most recent years, yet Iceland is still leading Nordic nations in the number of prescriptions (Directorate of Health 202I). However, if drugs are smuggled in large quantities from abroad, such measures might not show much impact on local black-market availability.

The supply and availability of drugs do not account for the high demand for these types of drugs in Iceland. Prescription drugs probably carry less stigma than illegal drugs and, therefore, may appear more attractive to larger groups of ordinary citizens than illicit drugs. As for legally prescribed drugs, alternatives to drug use, such as consulting and therapy - increased access to social and psychological services - are options that perhaps have not been utilized to the same degree as in other Nordic nations. 


\section{Risk Factors and Drug Abuse}

Studies show that alcohol and drug dependence can affect anyone; for instance, alcoholics seem to belong to all walks of life. Nevertheless, research indicates that a significant section of those who hit rock bottom due to heavy drug abuse, especially those who inject drugs, face various personal and social problems (see, for example, Curry I 994 and Zilney 20I I). Low formal education, limited work experience, health care problems, and crime-prone lifestyles are all factors associated with drug abuse (Goode 2015), and to a much larger degree than found in the general population. Research findings of this type on drug abuse in Iceland, fueled by the local opioid crisis, have raised questions about the most effective way to respond to the problem of drugs.

A recent study conducted in Iceland seems to support the above social portrayal of heavy drug abuse. Based on data from a national rehab clinic in Iceland, where information about close to 200 patients suffering from hard drug abuse (use of needles) was utilized during a two-year period, Aradóttir located (as cited in Gunnlaugsson 2015) a distinct social pattern. About half of the sample admitted upon entrance to the clinic that they had earlier been diagnosed with a disability of some sort and had limited work experience. The majority had only completed compulsory education. About $60 \%$ of the hard drug users in this study had previously been arrested or charged for drug violations, while only $25 \%$ of other patients at the clinic had the same experience. About one third admitted to having prior police history of thefts, frauds, or violence. Thus, it is evident that most hard drug users are crime-prone with prior police history. The vast majority suffered from mental health problems, depression, anxieties, and tension. More than $70 \%$ of these drug users had considered suicide and about half had attempted suicide. More than half had been diagnosed with liver problem $\mathrm{C}$ and a few with HIV. Of the females, the vast majority had experienced violence and about $75 \%$ of them reported having been sexually victimized.

Admissions to the national rehab center are in the thousands each year, as previously mentioned. Increasingly, more patients in this group are admitted due to drug dependence, and the rate of alcohol abuse alone has diminished in recent years (SÁÁ 202 I). In 
2017 , close to $40 \%$ of those admitted did not have any permanent housing, thereby suggesting poor social conditions, and about one quarter resided with their parents.

A survey conducted in Icelandic prisons in 2015 indicated similar results of poor standing among prisoners. The vast majority of inmates suffered from serious alcohol and drug problems and had been diagnosed with a variety of personal and social problems, including ADHD and reading and writing difficulties (Hlöðversdóttir 2015; Gunnlaugsson 2018).

Therefore, there seems to be a high polarization of drug users in society. A large part of the population, particularly young people, appear to be willing to experiment and use drugs recreationally without apparently harming themselves. A large minority, however, end up becoming serious drug abusers with multi-faceted personal and social problems, posing a risk to themselves and others. Research, both in Iceland and elsewhere, roughly seems to draw up this polarized picture of the drug problem.

Is the criminal justice response the appropriate measure to deal with the kind of behavior described above? Is an unregulated black market of drugs, including opioids, where consumer protection obviously is limited and appropriate education on how dangerous these drugs can really be not available, acceptable in modern-day welfare societies? In the wake of a public debate where questions of this type have appeared, harm reduction principles have slowly emerged in Iceland in recent years to tackle this profound problem with a new approach. The long history of treatment availability in Iceland, and wide recognition of its success in dealing with substance use, has undoubtedly helped in paving the way for an alternative approach.

Consequently, local harm reduction programs have been established in Iceland. As early as 2009, the Red Cross in Iceland launched a project on wheels, Frú Ragnheiður (Mrs. Ragnheiður), driving around the streets of the capital for six evenings a week (Frú Ragnheiður 2020). The vehicle is a specially equipped medical reception for the homeless and people with drug addictions, offering medical care and general health advice to individuals, as well as a service that exchanges old needles for new. In 2018 , approximately 450 individuals sought assistance from this program. 


\section{New Drug Alternatives in Iceland?}

A widespread consensus to continue with the firm stand against drugs has existed for a long time among Icelandic authorities. The public, at large, seems to support this national effort and moral sentiment. As population surveys have repeatedly indicated, there exists widespread opposition in Icelandic society toward drug use. In 20I4, the vast majority of Icelanders were in favor of offering more rights to the police to investigate drug crimes. Most respondents believe drug use to be the most serious crime in Iceland and substance use to be a decisive factor in the genesis of local crime (Gunnlaugsson 2018). In May of 2019, about $26 \%$ of all respondents favored the legalization of cannabis and $35 \%$ were in favor of the decriminalization of the possession of drugs for personal use (Gunnlaugsson \& Jónasson 20I9), so the significant majority of Icelanders were against both the legalization of cannabis and the decriminalization of drug use.

However, support for alternative drug policies has increased somewhat in recent years, suggesting a retreat from the punitive stand. As a case in point, about $80 \%$ of all respondents opposed the legalization of cannabis in 2012 , with fewer, or less than $70 \%$, opposing legalization in 2019 (Mbl.is 2019). Local efforts such as Frú Ragnheiður and evidence on the nature of drug abuse, as for example reflected in the opioid crisis, have paved the way for new approaches to the drug problem. Resultantly, the notion that drug abuse should be defined and treated as a public health problem instead of a criminal justice issue has become more prominent (for example, Holm 2015). In the last few years, alternatives to current drug legislations have consequently appeared in Iceland. Proposals have been introduced in Alpingi, with the intent to revise the local narcotics legislation. The primary focus has been on softening the ban on drugs to some extent, i.e., decriminalizing personal possession and use of drugs, particularly cannabis (see, for example, Alpingi 20I2-20I3). These proposals have typically generated widespread public debate in society. Even though not put into immediate effect, they still served to open up the drug debate in society, providing a platform for alternative actions adopted by the government later.

More active public debate on drugs can indeed be detected in Iceland. Different opinions have been raised on tackling the 
local drug issue, with seminars and conferences critically dealing with the drug problem (see, for example, Heilsutorg 20I4). Local grassroots groups (for example, Snarrótin 2020) offering alternative perspectives on the drug problem have also emerged. Individual political parties, such as the Pirate Party and young members of the Independence Party, have increasingly voiced alternative approaches in their party agenda.

In 20I4, the Minister of Health from the Independence Party publicly announced at a meeting with young members of his party that decriminalization of personal possession of drugs should be seriously considered by the local legal body. Subsequently, an expert committee was established to revise and introduce new drug legislation on the issue (Bjarnar 20I4). This move by the Minister of Health was unusual because drug controls and drug legislations, as previously mentioned, are formally located within the Ministry of Justice, and so this possibly reflects new voices in society that believe drug abuse to be a public health problem rather than a crime problem.

A report from the committee was eventually submitted to Alpingi in the name of the Minister of Health (20I6). The most noteworthy recommendation in the report was the discontinuation of registering minor possession of drugs on the criminal register and stopping the use of urine tests to determine whether individuals are driving while intoxicated. In 20I8, as previously mentioned, provisions concerning the criminal register notification were revised by the state prosecutor. Moreover, a proposal establishing a safe place for needle change and drug use was also included in the report. Such a safe site for those most affected by serious drug abuse would enable health workers to step in and assist them.

In May of 2020, Alpingi passed a new legal provision permitting local governments to open safe places for drug addicts (Alpingi 2020). However, as of early 202I, this place had not yet been opened, apart from the Red Cross program Frú Ragnheiður mentioned above. A critique raised belonged to the capital area police chief. Drugs used by addicts are controlled substances, and the local police are obligated to confiscate them. The police cannot look the other way and do nothing while illegal possession and the use of drugs are occurring in front of their eyes (Pétursson 
20I9). Despite opposition from the Icelandic police, a legal change allowing safe places for drug addicts was still approved by the local legal body.

As for driving while intoxicated, since 201 8, drug residuals found in urine samples cannot serve as a basis for conviction; only blood samples can be used (Icelandic Transport Authority 20I 8). In the past, many drivers who had drug residuals in their urine sample, such as THC from cannabis, which may have been consumed up to a month earlier, were at risk of being convicted for driving while intoxicated. Currently, only those who exhibit signs of drug intoxication at the time of driving, as shown in blood samples, can be convicted for driving while intoxicated (DWI).

These legal actions can be considered a sort of policy shift from the punitive stand against drugs and a minor step toward the decriminalization of the personal use of drugs, in addition to only punishing those who are shown to be intoxicated while driving a vehicle. This suggests a retreat in the battle against drugs, moving away from restrictive policies to a somewhat softer approach. However, possession of drugs for personal use is still punishable by Icelandic law, resulting in a fine.

In the fall of 2019, a new drug bill was introduced in Alpingi (Alpingi 2019a). Nine MPs out of a total of 63 members, representing five of the eight political parties in Alpingi, introduced a proposal calling for the decriminalization of possession of all drugs for personal use. The type and quantity of drugs were not specified in the preamble of the bill. Under this bill, receiving and buying drugs above an unspecified limit for personal use will continue to be illegal. Possession of drugs for personal use will only be regarded as a public health issue and not a penal one. The importation, production, and distribution of drugs continues to be prohibited. If this bill is passed, according to the preamble, supervised drug sites for serious drug abusers will become possible for the first time. An important reason for not establishing such sites earlier was that the possession of drugs for personal use is prohibited and punishable by at least a fine. This makes it challenging, if not impossible, for health care workers to provide the necessary health services to hard drug abusers. The positive outcome of the Portugal experience of decriminalization was cited as a source to 
justify the objectives of the proposal. However, as previously noted, safe places for drug addicts have now been allowed by the legal body.

This new proposal was finally defeated in an Alpingi vote by a large margin in late June of 2020 after a heated debate (Hrönn 2020). Realistically, it did not seem likely to be passed. Two of the political parties in the present coalition government in Iceland did not have representation among the sponsors of the bill. A proposal originating from the opposition is not likely to be passed. However, a proposal departing from the punitive stand on drugs had reached the legislative agenda in Alpingi and so symbolizes new voices and directions in dealing with the country's drug problem. An editorial in the most-read local newspaper openly supported the proposal, stating that the war on drugs had been lost (Sigurpórsdóttir 2019).

Interestingly, in January of $202 \mathrm{I}$ the Minister of Health announced plans to introduce a new bill in Alpingi calling for decriminalization of small amounts of drugs for personal use (Pearson 202I), based on the assumption that drug addiction is more of a public health issue than a crime problem, similar to the earlier bill defeated in June of 2020 . As a possible obstacle, the Directorate of Health repeatedly opposed a legal change of this type (see, for example, Alpingi 20I9b). Yet in January of 202I, a new direction could be detected. In a formal statement about the new bill, the Directorate of Health revealed a favorable stand on decriminalizing small amounts of drugs for drug addicts (Pórisdóttir 202I), although added a reservation that this was only to be approved if the legal reform was to be properly placed within a broader social policy on drugs. Therefore, it can be argued that a possible paradigm shift in dealing with drug abuse might be in the making in Iceland. However, the bill did not make it to a vote before the Alpingi recession in June of $202 \mathrm{I}$, and therefore did not pass.

\section{Concluding Remarks}

The free market is a fundamental doctrine of the European Union, the World Trade Organization, and other powerful institutions (Sulkunen 2009). However, the free-market ideology has 
not yet penetrated to any significant degree into the market for illegal drugs that are mostly used for recreational purposes in the western world. Punitive measures in the area of drug use are vigorously and morally defended by western authorities, including Nordic nations, as shown in this book, using the state apparatus to seek out and prosecute both drug producers and sellers - and in many countries, also drug users.

These efforts by the state are, in one way or another, justified by the principles of protecting the public - a similar battle to the one western authorities lost a long time ago in the struggle against alcohol (Gunnlaugsson 20I2). Even though actions adopted by governments to curb drug use contain the potential for subverting legal traditions of individual freedom, they are still believed to be necessary for ensuring public good.

Why has the state been able to both introduce and maintain this punitive grip over drugs in modern society? The relatively short history of the influx of drugs to the western world in the I960's and I970's most probably has something to do with the intensity of punitive state reactions today. As a case in point, tobacco and alcohol have a much longer history in western societies, with both being legal despite posing immense health risks. For Iceland, a small island nation far away from neighboring countries, drugs have been seen even more as an outside imposition threatening the nation, especially the young, possibly undermining the future of the nation. Drug use is risky and regular media reporting on devastating stories of drug abuse understandably alarms the general public.

A recent United Nations World Drug Report was blunt in its conclusion, claiming that criminal sanctions for drug use are not beneficial (World Drug Report 20I4). It is certainly worthwhile and interesting to speculate on what future drug legislation developments will occur, or will look like, in Iceland or other Nordic countries. Is it probable that many recreational drugs, such as cannabis, will be defined and regulated by law in the same manner as we define alcohol today, or even tobacco, as has been the case in, for example, many US states and Canada? General alcohol and tobacco prohibition seem somewhat out of place in modern-day society and are incongruent with our ideas of freedom and human 
rights, despite alcohol problems and the harms of tobacco both being well-known and serious (Gunnlaugsson 20I2). Will, similarly, the current prohibitive drug legislations be perceived in the future as both archaic and unjust, and perhaps even futile? In this respect, it is noteworthy that the use of tobacco has significantly decreased in recent years in many western societies without punitive measures. Perhaps the same can happen with recreational drugs, with its use being regulated through social and cultural norms instead of resorting to action by the criminal justice system.

If some of the drugs currently banned will eventually be regulated, or even legalized, will this inevitably result in increased public use with more health-related risks than we experience today? By allowing free-market forces to realize their full impact, legalization of the most common drugs - for example, cannabis - will most probably result in more general use of the drug, just as was the case previously with alcohol use (Gunnlaugsson 20I7). The temporary and experimental use of drugs, which primarily characterizes use today, as shown in this chapter, will most likely be replaced by more widespread and permanent use of drugs in older age groups. Preliminary results from the legalization of marijuana in the US have been followed by lower prices, a dual legal and illegal market, and - in some instances - more problematic use (Savona, Kleiman \& Calderoni 20I7). Yet, it is probably too early to be conclusive about the outcome of the recent legalization in the US and Canada. Nevertheless, we might still expect that these changes are not altogether unproblematic.

Contrarily, it is not self-evident that the legalization of drugs necessarily includes free marketization and increased drug use. The supply of drugs and market availability could instead be regulated through similar sources as common medicines and drugs. Even state monopoly on alcohol sale restrictions, as are currently present in several Nordic nations, are also possible options for distributing recreational drugs. Sale arrangements, however, rely on political decisions and, obviously, many different policy choices are open to policymakers if the ban on drugs is relaxed, or even lifted, in the future.

As for the decriminalization of the possession of drugs for personal use, it is evident that it does not include the free marketization 
of drugs. The production and sale of drugs continue to be banned and will, therefore, not be placed on the free market with decriminalization. As early signs suggest (Drug Policy Alliance 20I9; Hughes \& Stevens 20I0; Quintas \& Arana 20I7), decriminalization policies do not necessarily result in increased drug use where these policies have been enacted.

As for Iceland, which only legalized beer in I989, a major legal change might seem unlikely. More liberal alcohol policies, including the legalization of beer, have indisputably increased the total amount of alcohol consumed in Iceland in recent years (Gunnlaugsson 20I7). Alcohol use among youth, however, has not increased as many beer opponents had feared. Some new, local signs pointing toward a retreat of the firm punitive stand against drugs have, nevertheless, appeared in Iceland, suggesting a possible paradigm shift in the future. This retreat has largely centered on reacting against drug abuse, fueled by the local opioid crises. As the review above indicates, the notion that drug abuse is a public health issue instead of a crime problem has increasingly gained a foothold in Icelandic society. This has been most clearly shown in the legal change allowing safe havens for drug addicts in 2020 and a new decriminalization proposal from the Minister of Health in $202 \mathrm{I}$.

However, recreational drug use as a legally and socially accepted policy in Iceland might seem farther away, as public opinion surveys have repeatedly shown. Social and cultural aversion of drugs in Iceland, revealed in local surveys, do not suggest immediate public support for decriminalization proposals. Nevertheless, more active public debate on drug policy alternatives in most recent years might possibly change the public mind in the foreseen future. Legal reforms, including reduced punishment for the importation, production, and sale of drugs, not to mention legalization of all drugs, have moreover not yet appeared in the legislative body of Alpingi. The criminal courts routinely mete out relatively harsh punishments for these types of drug offenses without any notable opposition from the public or government officials alike. Recent prison figures of drug offenders show no retreat of punitive practices, reaching a historic high in 2018 and 2019 with about $40 \%$ of the total inmate population serving time for drug-related offences. 
A thorough restructuring of the Icelandic drug laws toward a non-punitive drug policy, where the production, sale, and use of drugs are legally regulated, seems more likely to be adopted in Iceland as part of a broader multi-nation effort, rather than Iceland acting alone. Nordic nations, being internationally recognized welfare societies, could be ideal candidates to adopt alternative and more humane drug policies in the future. Nordic nations, however, currently offer different drug policies, as shown in this book, which might make a unified Nordic drug policy seem unlikely.

\section{References}

Alpingi Debates. (I983-1984a). Aðgerðir gegn innflutningi og dreifingu fíkniefna [Actions against importation and distribution of drugs]. I06. löggjafarping. Pingskjöl A. Tillaga til pingsályktunar [Alpingi Resolution], greinargerð [Preamble] (I 25. mál), pp. I-6. Retrieved February 3, 202 I: https://www.althingi.is/thingstorf /thingmalalistar-eftir-thingum/ferill/? $1 \mathrm{tg}=\mathrm{I} 062 \mathrm{Kmnr}=\mathrm{I} 25$.

Alpingi Debates. (1983-1984b). Aðgerðir gegn innflutningi og dreifingu fíkniefna [Actions against importation and distribution of drugs]. I06. löggjafarping. Sjá dálk 2254 í B-deild, (I25. mál). Alpingistíðindi. Part B, pp. I. Retrieved February 3, 202 I: https:// www.althingi.is/altext/raeda/?lthing= I06\&rnr=I 982 .

Alpingi. (20I2-20I3). Tillaga til pingsályktunar [Alpingi

Resolution]. I4 I. löggjafarping 20I2-I3. Pingskjal I 2 I4. 675. mál. Retrieved February 3, 202 I : https://www.althingi.is/altext /I 4 I/s/I 2 I 4.html? fbclid=IwAR2_kW 5 Qckz92kIEslEzMepBsCNa NmtnMIF 5 GqmO-NibXIJMo4JRooWETwc.

Alpingi. (20I9a). 23-23. mál, Frumvarp til laga: um breytingu á lögum um ávana- og fíkniefni, nr. 65/I974 (varsla) [Law proposal: On changing the narcotics law no. 65/I974 (possession)]. Alpingi. Retrieved October 22, 2019: https://www.althingi.is /altext/pdf/I 50/s/0023.pdf.

Alpingi. (20I9b). Umsögn um frumvarp til laga um breytingu á lögum um ávana- og fíkniefni, nr. 65/I974 (varsla) [Comment on a bill of a legal change regarding possession of drugs]. Retrieved January 27, 202 I: https://www.althingi.is/pdf/erindi_mals/? lthing $=\mathrm{I} 50 \&$ malnr $=23$. 
Alpingi. (2020). Lög um breytingu á lögum um ávana- og fíkniefni nr. 65/1974 með síðari breytingum (neyslurými) [Amendment on the law on drugs no. 65/I974 including later changes (consumption rooms)]. Retrieved February I, 202 I: https://www.althingi.is /altext/stjt/2020.048.html.

Arnórsson, M. (20I 8). Notkun geðlyfja á Íslandi [Use of psycholeptics in Iceland]. Icelandic Medicines Agency. Retrieved January 7, 20I9: https://www.lyfjastofnun.is/utgefid-efni /greinar_utgefid_efni/notkun-gedlyfja-a-islandi.

Bjarnar, J. (20I4, February I4). Heilbrigðisráðherra vill endurskoða refsistefnu í fíkniefnamálum [The Minister of Health in favor of revising punitive drug policies]. Visir.is. Retrieved February I, 202 I: https://www.visir.is/g/20I4I 402 I 9347 /heilbrigdisradherra-vill-endurskoda-refsistefnu-i-fiknefnamalum.

Brynjólfsson, A. (20I9, October I3). Mikið framboð af kókaíni á markaði hér [A lot of cocaine on the market here]. Fréttablaðið. Retrieved February 3, 202 I: https://www.frettabladid.is/frettir /mikid-frambod-her-kokaini/.

Böðvarsdóttir, E. M. (2020, January 29). 25 I beiðni um hlerun sampykkt á fimm ára tímabili [25 I wiretapping requests permitted during a five-year period]. Visir.is. Retrieved February I, 202 I: https://www.visir.is/g/2020200I28843/25 I-beidni-um -simahlerun-samthykkt-a-fimm-ara-timabili?fbclid=IwAR o6ya4xJN30JhBAngnz88oENu4 $\mathrm{M}_{5} \mathrm{LC}_{5} \mathrm{f}_{77} \mathrm{olog}_{3} \mathrm{od}_{7} \mathrm{MaK}_{3}$ QNYcoI-LPlcqI.

Curry, E. (1994). Reckoning: Drugs, the cities, and the American future. New York: Hill and Wang.

Demant, J., Bakken, S., Oksanen, A., \& Gunnlaugsson, H. (2019). Drug dealing on Facebook, Snapchat and Instagram: A qualitative analysis of novel drug markets in the Nordic countries. Drug and Alcohol Review, 38(4), 377-385.

Directorate of Health. (20I7). Áfengisneysla á siðustu I 2 mánuðum eftir kyni, aldri og menntun [Alcohol use in the last I 2 months by sex, age and education]. Reykjavík: Landlæknir (Directorate of Health). Retrieved February 6, 2020: https://www.landlaeknir .is/um-embaettid/greinar/grein/item 35858 /Tolulegar-upplysingar -ur-Heilsa-og-lidan-Islendinga. 
Directorate of Health. (202I). Próun í notkun ópíóiða [Trends in opioid use]. Talnabrunnur, I5(4), pp I-4. April. Reykjavík: Landlæknir (Directorate of Health). Retrieved March 29, $202 \mathrm{I}$ : https://www.landlaeknir.is/servlet/file/store93/item4480 I /Talnabrunnur_April_202I.pdf.

Drug Policy Alliance. (2019). Drug decriminalization. Drug Policy. Retrieved October 23, 20I9: http://www.drugpolicy.org/issues /drug-decriminalization.

Einarsson, Á., \& Björnsson, G. R. (Eds.) (200I). Fíkniefni og forvarnir handbók fyrir heimili og skóla [Drugs and preventive measures for households and schools]. Reykjavík: Fræðslumiðstöð í fíknivörnum.

ESPAD. (2020). The ESPAD Report 2019: Results from the European School Survey Project on Alcohol and other Drugs. Luxemborg: European Monitoring Centre on Drugs and Drug Addiction og European School Survey Project on Alcohol and Other Drugs. Retrieved March 2, 202 I: http://espad.org/sites /espad.org/files/2020.3878_EN_04.pdf.

Frú Ragnheiður. (2020). Hvað gerum við [What we do]. Rauði Krossinn í Reykjavík. [Reykjavík Red Cross]. Retrieved February 5, 2020: https://www.raudikrossinn.is/english/programmes /harm-reduction/.

Goode, E. (201 5). Drugs in American society. 9th edition. Boston: McGraw Hill.

Goode, E., \& Yehuda, N. B. (2009). Moral panics: The social construction of deviance. 2nd edition. Oxford: Wiley-Blackwell.

Gunnlaugsson, H. (2OI2). Extreme case of life-style regulation: Prohibition of beer in Iceland I9I 5-I989. In M. Hellman, G. Roos, \& J. v. Wright (Eds.), A welfare policy patchwork Negotiating the public good in times of transition (pp. 259-276). Helsinki: The Nordic Centre for Welfare and Social Issues (NVC).

Gunnlaugsson, H. (201 5). Drug use and drug controls in Iceland: An historic paradigm in sight? In H. Giertsen, \& $\mathrm{H}$. Gunnlaugsson (Eds.), Drugs: What is the problem and how do we perceive it? Policies on drugs in Nordic countries: NSfK Working Group Report (pp.90-I03). Aarhus: Scandinavian 
Research Council for Criminology. Retrieved October 22, 2019: https://www.jus.uio.no/ikrs/english/research/publications/20I5 /drugs-problem.html.

Gunnlaugsson, H. (20I7). Iceland's peculiar beer ban, I9 I 5-I989. In E. U. Savona, M. A. R. Kleiman, \& F. Calderoni (Eds.), Dual markets: Comparative approaches to regulation (pp. 237-248). Cham: Springer.

Gunnlaugsson, H. (20I8). Afbrot og íslenskt samfélag [Crime and Icelandic Society]. Reykjavík: Háskólaútgáfan.

Gunnlaugsson, H. (2019). Stofproblemet i Island: Opioid krisen giver alvorlige bekymringer. STOF. Nr. 33, 80-85. Aarhus: Center for Rusmiddelforskning.

Gunnlaugsson, H., \& Galliher, J. F. (I995). The secret drug police of Iceland. In G. Marx, \& C. Fijnaut (Eds.), Undercover: Police surveillance in comparative perspective (pp.235-247). The Hague: Kluwer Law International.

Gunnlaugsson, H., \& Galliher, J. F. (2000). Wayward Icelanders: Punishment, boundary maintenance and the creation of crime. Madison: University of Wisconsin Press.

Gunnlaugsson, H., \& Galliher, J. F. (2010). Drug globalization: Eventual legalization of beer in Iceland and marihuana decriminalization in the USA. Journal of Scandinavian Studies in Criminology and Crime Prevention, II(2), I I9-I34.

Gunnlaugsson, H., \& Jónasson, J. O. (2019). Er neysla Íslendinga á kannabis að aukast og afstaða peirra i fíkniefnamálum að breytast? [Is cannabis use increasing in Iceland and public attitudes toward drug policies changing?]. Paper presented at Pjóðarspegillinn at University of Iceland, November I, 20 I9.

Hansdóttir, I., Rúnarsdóttir, V. Á., \& Tyrfingsson, P. (2OI 5 ). Addiction treatment in Iceland. In N. el-Guebaly, G. Carrá, \& M. Galanter (Eds.), Textbook of Addiction Treatment: International Perspectives (Vol I), pp. I I99-I 207. Milan: Springer.

Helgason, S. (20I9, October I3). Prjú stærstu kókaínmál sögunnar á árinu [Three biggest cocaine cases in history this year]. RUUV. 
Retrieved October 22, 20I9: https://www.ruv.is/frett/thrju -staerstu-kokainmal-islandssogunnar-a-arinu.

Heilsutorg. (20I4). Er vit í vímuefnavísindunum? (Is there any sense in drugs research?) Fyrirlestur prófessors David Nutt I 6. september stofu IO2 á Háskólatorgi, Sæmundargötu 4 IOI Reykjavík (A public lecture by Professor David Nutt September I 6 at University of Iceland). Retrieved August I I, 202 I: https:// www.heilsutorg.is/is/frettir/er-vit-i-vimuefnavisindum.

Hlöðversdóttir, H. (201 5). Pað er ástæða fyrir endurkomum, engin vinna eða toekifori og enginn geðloeknir [There is a reason for repeat offending, no job, no opportunity and no psychiatrist]. Unpublished master's thesis in Sociology. Reykjavík: University of Iceland.

Holm, H. (20I5, October I I). Segja fíkniefnaneyslu vera heilbrigðismál [Claim drug use is a health care issue]. RÚV. Retrieved February I, 202 I: https://www.ruv.is/frett/segja -fikniefnaneyslu-vera-heilbrigdismal.

Hrönn, G. (2020). Frumvarp Pírata um afglæpavæðingu á neyslu vímuefna fellt [Pirate's proposal to decriminalize use of drugs defeated]. Mannlif.is. Retrieved August I I, 202 I: https://www .mannlif.is/frettir/frumvarp-pirata-um-afglaepavaedingu -neyslu-vimuefna-fellt/.

Hughes, C. E., \& Stevens, A. (2010). What can we learn from the Portuguese decriminalization of illicit drugs? British Journal of Criminology, 50, 999-1022.

Icelandic Transport Authority. (20I8). Reglugerð um sektir og önnur viðurlög vegna brota á umferðarlögum og reglum settum samkvæmt peim [Regulations on fines and other sanctions on traffic related violations]. Retrieved February 4, 2020: https:// www.samgongustofa.is/media/log-og-reglur-i-umferdarmalum/B _nr_288_20I8.pdf.

Jónasson, J. O. and Gunnlaugsson, H. (2015). Moral panic in Icelandic society: Arrival of ecstacy to Iceland in the I990's. In Giertsen, H. and Gunnlaugsson, H. (eds.). Drugs: What is the Problem and How Do We Perceive it? Policies on Drugs 
in Nordic Countries. NSfK Working Group Report, pp 47-6I. Århus: Scandinavian Council for Criminological Research.

Jónsson, S. M. (20 I 8a). Fimmta hver kona á Íslandi tekur lyf við punglyndi [One-fifth of all Icelandic women receives prescribed anti-depressants]. Fréttablaðið, November 22, 4.

Jónsson, S.G. (20I 8b). 42 létust vegna ópíata sî̉ustu prjú ár [42 died due to opioids abuse in the last three years]. Stundin, August 24. Retrieved February I, 202 I: https://stundin.is/grein/732I/.

Katz, J. (20I7, August I0). Short answers to hard questions about the opioid crisis. New York Times. Retrieved February I, 202 I: https://www.nytimes.com/interactive/20I7/08/03/upshot/opioid -drug-overdose-epidemic.html.

Kristmundsson, Ó. H. (I985). Ólögleg ávana- og fíkniefni á Íslandi [Illegal drugs in Iceland]. Reykjavík: Dóms- og kirkjumálaráðuneytið.

Magnúsdóttir, M. Ó. (20I9, January 8). Talið að 52 hafi látist vegna ofneyslu í fyrra [Estimated that 52 died due to overdose last year]. $R U ́ V$. Retrieved January 8, 20I9: http://www.ruv.is/frett /talid-ad-52-hafi-latist-vegna-ofneyslu-i-fyrra.

Mannlif. (I992). Stríðið við sölumenn dauðans [The war against the dealers of death]. Vol. 9, no. 9 November: 6-I 5, Reykjavík.

Mbl.is. (2014, February 19). Birtist á sakavottorði í prjú ár [Appears on criminal record for three years]. Mbl.is. Retrieved October 23, 20I9: https:/www.mbl.is/frettir/innlent/20I4/o2/I9/birtist_a _sakavottordi_i_thrju_ar/.

Mbl.is (2018, June 25). 90 fíkniefnamál á Secret Solstice (A total of 90 drug cases at the Secret Solstice). Mbl.is. Retrieved August I9, 202 I: https://www.mbl.is/frettir/innlent/20 I 8/06/25/90 _fikniefnamal_a_secret_solstice/.

Mbl.is. (2019, June 5). Priðjungur prófað kannabis [One-third tried cannabis]. Mbl.is. Retrieved February 26, 2020: https://www.mbl .is/frettir/innlent/20I9/06/o5/thridjungur_notad_ologleg_efni/.

Minister of Health Report. (20I6). Mótun stefnu til að draga úr skaðlegum afleiðingum og hliðarverkunum vímuefnaneyslu. [Minister of health policy report to reduce harm due to 
substance use]. Lögð fyrir Alpingi á I 45. löggjafarpingi 20I 52016. Submitted to Alpingi (Iceland Parliament).

Ministry of Justice. (20I8). Svar dómsmálaráđherra: Skráning vímuefnabrota á sakaskrá [Briefing from the Minister of Justice: Registration of drugs violations on criminal record]. Pingskjal 480-223. mál, 20I8-20I9. Retrieved February 24, 2020: https:// www.althingi.is/thingstorf/thingmalalistar-eftir-thingum /ferill/? $\operatorname{ltg}=\mathrm{I} 49 \& \mathrm{mnr}=223$.

Morgunblaðið. (I979, December I4). Fíkniefnamálið verður sífellt alvarlegra: Ungmenni láta lífið vegna fíkniefnaneyslu [The drug problem increasingly more serious: Young people die due to drug use], pp. I7, 32 .

Morgunblaðið. (I993, May 22). Rannsóknaraðferðir innan eðlilegra marka [Investigative methods within legal limits], p. 25.

Nadelmann, E. A. (I993). Cops across borders: The Internationalization of U.S. criminal law enforcement. University Park, Pa.: Pennsylvania State University Press.

National Commissioner of the Icelandic Police. (2008). Afbrotatölfrceði 2007 (Criminal Statistics 2007). Ríkislögreglustjórinn. Retrieved February 6, 2020: https://dev .logreglan.is/wp-content/uploads/20 I 4/I 2/Afbrotat $\% \mathrm{C}_{3}$ $\%$ B6lfr\% $\%$ \% A6\%C3\%Boi-RLS_2007.pdf.

National Commissioner of the Icelandic Police. (2020). Afbrotatölfrceði 2019 (Criminal Statistics 20I9). Retrieved August I2, 202I: https://www.logreglan.is/wp-content/uploads /2021/02/Afbrotatolfraedi-2019.pdf.

Nomesco. (2017). Drug related deaths in the Nordic countries: Revision of the statistical definition. Nomesco, Copenhagen I08: 20I7. Retrieved January 7, 20I9: http://norden.diva-portal.org /smash/get/diva2:I I 70945/FULLTEXTor.pdf.

OECD Health Statistics. (2020). Alcohol consumption in liters per capita (ages I 5+). OECD. Retrieved February 7, 2020: https:// data.oecd.org/healthrisk/alcohol-consumption.htm.

Ólafsdóttir, K. (2019, January 3). Yfirlæknir á Vogi segir aðgengi að dópi mjög gott og lýsir lækkandi verði [Head physician at the 
Vog Rehab Center claims access to drugs is easy and price going down]. Visir.is. Retrieved February I, 202 I: https://www.visir .is/g/20I9758 I69d.

Pearson, J. (202 I, January 2I). Icelandic government proposes drug decriminalization. Reykjavík Grapevine. Retrieved February 3, 202 I: https:/grapevine.is/news/202I/OI/2I/icelandic-govern ment-proposes-drug-legalisation/?fbclid=IwAR $2 \mathrm{dBvwH} 7 \mathrm{zIZu}$ XFysoDURbGtieG_dNTFFiWc_Qa29I8N8FDoXTo2LnumFPk.

Pétursson, H. (2019, April I7). Lögregla leggur til breytingar á frumvarpi um neyslurými [Police submits amendments on safe drug use bill]. Visir.is. Retrieved February 27, 2020: https://www .visir.is/g/20 I 91904 I 899 I/logregla-leggur-til-breytingar -a-frumvarpi-um-neyslurymi.

Prison and Probation Administration. (2020). Ársskýrslur (Annual Reports). Fangelsismálastofnun ríkisins. Retrieved February 6, 2020: https://www.fangelsi.is/english.

Quintas, J., \& Arana, X. (20I7). Decriminalization: Different models in Portugal and Spain. In E.U. Savona, M. A. R. Kleiman, \& F. Calderoni (Eds.), Dual markets: Comparative approaches to regulation (pp. I 2 I-I 44). Cham: Springer.

Savona, E. U., Kleiman, M. A. R., \& Calderoni. F. (Eds.) (2017). Introduction. Dual markets: Comparative approaches to regulation (pp. I 2 I-I 44). Cham: Springer.

SÁÁ. (202I). National Center of Addiction Medicine (SÁÁ). Upplýsingar um pjónustu samtakanna I977-20I 8 [Service information I977-20I8]. Retrieved March 29, 2021: https://saa.is /english/.

Sigurpórsdóttir, S. K. (2019, October I6). Búið spil [End of game]. Visir.is. Retrieved February 27, 2020: https://www.visir.is /g/201919101 8976/buid-spil-.

Snarrótin. (2020). Snarrótin, félag áhugamanna um opið samfélag, mannréttindi, upplýsingafrelsi og nýjar leiðir í fíknivörnum [NGO on open society, human rights, free information and alternative approaches to the drug problem]. Snarrótin. Retrieved February 5, 2020: http://snarrotin.is/markmid-og-leidir/.

Sulkunen, P. (2009). The saturated society: Governing risk and lifestyles in consumer culture. London: Sage. 
Supreme Court. (2009). Dómsúrlausn Hæstaréttar [Supreme Court decision]. Mál nr. 509/2009, fimmtudaginn 3. desember 2009. Retrieved February 7, 2020: https://urlausnir.stuff.is/skrar /einstakar_urlausnir/hrd_2009-509\% 20dags.\%203.\% 20de sember \% 202009\% 20(F\%C3\%ADkniefni\% 20\% $3 \%$ Ar \% 20 sk $\left.\% \mathrm{C}_{3} \% \mathrm{BAtu}\right) . p d f$.

Supreme Court. (20I6). Dómsúrlausn Hæstaréttar [Supreme Court decision]. Mál nr. 735/201 5, fimmtudaginn 4. febrúar 2016. Retrieved February 7, 2020: https://www.haestirettur .is/default.aspx? pageid $=347 \mathrm{c} 3 \mathrm{bb}$ - -8926 - I Ie 5-80c6-005056 bc6a4o\&id $=4 a_{5} 4 f_{9} b_{3}-8$ oca- 4 d $90-a_{5}$ e- $3 d_{3} 3$ cfc6 Iab $_{4}$.

Visir.is. (2007, December 7). Stóraukin kannabisræktun [Massproduction of cannabis on the rise]. Fréttablaðið, p. I. Retrieved March I7, 202 I: https://www.visir.is/paper/fbl/o7 I 204.pdf.

World Drug Report 20I4. (20I4). World Drug Report 20I4. United Nations Office on Drugs and Crime (UNODC). Retrieved March 29, 202 I: https://www.unodc.org/documents/wdr20 I 4/World _Drug_Report_20I4_web.pdf.

Yaghi, N. G. (2019, October 2I). Tuttugu og prír létust af völdum sterkra verkjalyfja í fyrra [Twenty-three died due to strong pain killers last year]. Visir. Retrieved February 8, 202 I: https://www .visir.is/g/20I9I 9 I0298 Io/tuttugu-og-thrir-letust-af-voldum -sterkra-verkjalyfja-a-islandi-i-fyrra.

Young, E. (2019). From teens in Iceland to Planet Youth: What happened after our story on Iceland? Mosaic. Retrieved February I, 202 I: https://mosaicscience.com/story/teens-iceland-planet -youth-what-happened-after-our-story-iceland/.

Zilney, L. A. (20I I). Drugs policy, social costs, crime, and justice. Boston: Prentice Hall.

Pórisdóttir, A. L. (202 I, January 29). Landlæknir styður afglæpavæðingu neysluskammta [Directorate of health supports decriminalization of drugs for personal use]. RÚV. Retrieved February I, 202I: https://www.ruv.is/frett/202I/OI/29/land laeknir-stydur-afglaepavaedingu-neysluskammta.

Pórmundsson, J. (I980). Opinbert réttarfar [Criminal Justice]. 2nd edition. Reykjavík: University of Iceland Press. 